Лідія ШШВЕЛІДЗЕ,
orcid.org/0000-0003-2291-5255
стариий викладач кафедри англійської філологї та перекладу
Одеського національного політехнічного університету

(Oдеса, Україна) 9087000@gmail.com

\title{
ТАКТИКИ КОНФЛІКТНОЇ КОМУНІКАЦІЇ В МЕРЕЖЕВОМУ ПОЛІТИЧНОМУ ДИСКУ РСІ США ТА УКРАЇНИ (НА МАТЕРІАЛІ ПОВІДОМЛЕНЬ У ТВІТЕРІ)
}

\begin{abstract}
Статтю присвячено вивченню мережевого політичного дискурсу в лінгвопрагматичному аспекті. Розглянуто дискурсивні характеристики сочіальних мереж, щчо є одним із каналів репрезентації політичного дискурсу. Основну увагу приділено соиіальній мережі Твітер та дописам - твітам - відомих політиків США та України. Мета дослідження передбачала визначення специфіки конфліктного спілкування в мережевому політичному дискурсі США та України та виокремлення основних тактик конфліктної взаємодії. Це зумовило розв'язання основних завдань, таких як: узагальнити дефініиії стратегій і тактик спілкування; визначити специфіку конфліктного спілкування; проаналізувати основні конфліктні тактики у твітах американських та українських політиків; обтрунтувати типологію тактик у політичному мережевому дискурсі. У статті використано такі методи дослідження: описовий із метою узагальнення поглядів дослідників на проблему стратегій $і$ тактик у спілкуванні; функиійний - для вивчення основних функиій мовних засобів у вираженні конфліктної комунікативної настанови учасників спілкування; лінгвопрагматичний - для виявлення специфіки реалізованих комунікативних тактик.

У межах конфліктної взаємодії в політичному твітингу виокремлено основні тактики спілкування: звинувачення, образи, критики та самокритики. Кожну комунікативну тактику проілюстровано відповідними дописами політиків США (Д. Трампа, Дж. Байдена, Х. Клінтон, Б. Сандерса та ін.) та Украӥні (А. Авакова, П. Порошенка, О. Ляшка, А. Яценюка та ін.). Доведено, щзо тактики звинувачення, критики та образи представлені в комунікативній поведінці американських та украӥнських політиків однаковою мірою, проте в політиків США їх реалізація має експлічиттний характер, а в украӥнських політиків - здебільшого імпліцитний характер. Тактика самокритики характерна виключно для украӥнського політичного твітингу. Простежено специфріку реалізаиії кожної тактики в американському та украӥнському політичному мережевому дискурсі в зіставному аспекті.

Ключові слова: мережевий дискурс, політичний дискурс, конфліктне спілкування, комунікативна тактика, політичний твітинг, твіт.
\end{abstract}

Lidiia SHVELIDZE,

orcid.org/0000-0003-2291-5255

Senior Lecturer at the Department of English Philology and Translation

Odesa National Polytechnic University

(Odesa, Ukraine)9087000@gmail.com

\section{CONFLICT COMMUNICATION TACTICS \\ IN THE NETWORK POLITICAL DISCOURSE OF THE USA AND UKRAINE (BASED ON THE TWITTER MATERIALS)}

The article focuses on the study of network political discourse in the linguopragmatic aspect. The discursive characteristics of social networks, which is one of the channels of representation of political discourse are considered. The attention is paid to the social network Twitter and posts - tweets - of famous American and Ukrainian politicians. The purpose of the study was to determine the specifics of conflict communication in the network political discourse of the United States and Ukraine and to identify the main tactics of conflict interaction. This has led to the solution of the main tasks: to generalize the definitions of communication strategies and tactics; to determine the specifics of conflict communication; to analyze the main conflict tactics in the tweets of American and Ukrainian politicians; to substantiate the typology of tactics in political network discourse. Methods used in the following research are descriptive which is used in order to generalize the views of the researchers on the problem of strategies and tactics in communication, functional used to study the basic functions of language in the expression of conflicting communicative guidelines of communication participants, and linguopragmatic - to identify the specifics of the implemented communication tactics.

Within the framework of conflict interaction, the main tactics of communication are singled out in political tweeting, they are accusations, insults, criticism and self-criticism. Each communication tactic is illustrated by relevant posts of US politicians (D. Trump, J. Biden, H. Clinton, B. Sanders, etc.) and Ukrainian ones (A. Avakov, P. Poroshenko, 
O. Lyashko, A. Yatseyuk, etc.). It is proved that the tactics of accusations, criticism and insults are presented equally in the communicative behavior of American and Ukrainian politicians, however, their implementation is explicit among US politicians, and mostly implicit among Ukrainian politicians. Self-criticism tactics are typical exclusively for Ukrainian political tweeting. The specifics of the implementation of each tactic in the American and Ukrainian political network discourse in a comparative aspect are traced.

Key words: network discourse, political discourse, conflict communication, communicative tactics, political tweeting, tweet.

Постановка проблеми в загальному вигляді. Дослідження комунікативної взаємодії в інтернет-комунікації передбачає аналіз різних жанрових форм спілкування, зокрема представлених у соціальних мережах. Вибір певного вектору такої взаємодії зумовлює реалізацію комунікативного завдання iï учасників та прогнозує успішність або неуспішність спілкування. У соціальних мережах взаємодія опосередкована каналом комунікації та характеризується певним ступенем спонтанності, що забезпечує ії інтерактивний характер, незважаючи на письмову форму. Одним із виявів мережевого спілкування $€$ обмін повідомленнями у Твітері, популярній світовій соцмережі. Обмеження обсягу повідомлення (140 символів) та зручність у використанні забезпечила цій соцмережі успіх як серед пересічних користувачів, так і публічних осіб. Зважаючи на це, Твітер використовують і в політичному дискурсі: відомі публічні особи та політики є активними дописувачами на своїх сторінках, здійснюючи в такий спосіб комунікації як між собою, так і з потенційними прихильниками або опонентами. Твітер останнім часом виконує роль своєрідного комунікативного простору, в межах якого комуніканти висловлюють та аргументують свою позицію в лаконічній формі, спираючись на можливості інтернет-дискурсу забезпечувати оперативність та поліфункційність спілкування. 3 огляду на це набуває актуальності лінгвопрагматичний аспект мережевого спілкування, зокрема його стратегічні параметри. Цей факт спричиняє необхідність розмежовувати кооперативне і конфліктне спілкування, що передбачає доцільність аналізу конфліктних комунікативних тактик (далі - КT) у політи чному мережевому дискурсі.

Мета дослідження полягає у визначенні тактик конфліктного спілкування в мережевому політичному дискурсі США та України, що визначило поставлені завдання: узагальнити основні дефініції стратегій і тактик спілкування; визначити специфіку конфліктного спілкування; проаналізувати основні конфліктні тактики в твітах американських та українських політиків; обгрунтувати типологію КТ уполітичному мережевому дискурсі.

Об'єктом аналізу слугував мережевий дискурс, репрезентований в українському і американ- ському Твітері; а предметом - обрані комунікантами тактики конфліктного спілкування.

У статті використано такі методи дослідження: описовий, із метою узагальнення поглядів дослідників на проблему стратегій і тактик у мережевому спілкуванні; функційний - для вивчення основних функцій мовних засобів у вираженні конфліктної комунікативної настанови учасників спілкування; лінгвопрагматичний - для виявлення специфіки використаних комунікативних тактик.

Ступінь дослідження проблеми в лінгвістиці. Активний розвиток лінгвопрагматики в останні десятиліття має результатом напрацьовану теорію з інтенційних і стратегічних параметрів комунікативної взаємодії. Проблеми витлумачення мовленнєвих стратегій і тактик порушено у працях зарубіжних (Т. ван Дейк, О. Іссерс, Т. Янко та ін.) та українських (Ф. Бацевич, Н. Кондратенко та ін.) мовознавців. Особливу увагу приділено стратегіям взаємодії учасників політичного дискурсу (О. Паршина, Л. Славова, О. Билінська, Л. Завальска та ін.), проте аналіз КС у мережевому дискурсі має поодинокий характер (С. Нерян, та ін.). Загалом дослідження мережевої комунікації, зокрема твіту як одного з їі жанрів, $є$ наразі актуальним і перспективним (О. Горошко, Т. Полякова та ін.). Простеження реалізації конфліктних КС у мережевому політичному дискурсі дозволить скерувати лінгвопрагматичні розвідки в бік дослідження інтенцій і результатів спілкування.

Виклад основного матеріалу дослідження. Сучасні лінгвісти визначають стратегії комунікації як компонент «евристичної інтенційної програми планування дискурсу» (Селіванова, 2008: 607), комплекс дій, що «спрямовані до досягнення комунікативного завдання» (Иссерс, 2003: 54), лінгвопрагматичні «принципи реалізації іллокутивного смислу» (Седов, 2004: 35). Грунтуючись на наведених вище дефініціях, потрактовуємо стратегії як загальний напрям комунікативної взаємодії, визначений мовцем 3 огляду на власну інтенцію спілкування. Зважаючи на це, основними формами комунікації $\epsilon$ кооперація і конфлікт, що є асиметричними 3 боку комунікативного завдання, статусу комунікантів та використаних засобів (Селіванова, 2008: 608). Г. П. Грайс визначає кооперацію 
як такий тип взаємодії, за якого для кожного учасника «комунікативний внесок мусить бути такими, якого потребує спільна мета спілкування» (Грайс 1985). У такому разі якщо кооперація передбачає наявність спільного комунікативного завдання та прагнення досягти успіху, конфлікт вказує на відсутність спільної інтенції. На нашу думку, в політичному дискурсі конфліктна взаємодія завжди спрямована на дискредитацію політичного опонента, що становить їі інтенційну сутність. Невипадково деякі дослідники визначають дискредитацію як основну стратегію взаємодії політиків. Вважаємо, що в межах конфліктної стратегії політичного спілкування доцільно виокремити відповідні комунікативні тактики. Л. Славова визначає тактики інвективи, агресії, дискредитації, домінування, маніпуляції, нав'язування свого бачення (Славова, 2012: 89). А нашу думку, дискредитація є підгрунтям політичних конфліктів, що виявляється і в мережевому спілкуванні через Твітер.

На лексичному рівні дискредитація виражається за допомогою оцінної лексики, зокрема адресованої політичним опонентам, напр.: ...obama killed the pharmaceutical manufacturing business in Puerto Rico. We are bringing it back from China and other faraway lands (Д. Трамп, 19.09.2020). У такому разі наявна апеляція до опонента, переважно в імпліцитній формі (об'єкт обговорення, a не адресат) i негативно оцінна характеристика його дій. У наведеному прикладі Д. Трамп характеризує дії свого попередника Б. Обами як «вбивство» фармацевтичного виробництва, вживаючи метафору 3 яскравою семантикою та образністю. Лінгвокреатив у конфліктній взаємодії у Твітері представлений і через оказіональну лексику, напр.: Trump has spent his entire political career demonizing immigrants. He's caged migrant babies at the border. He's used fear of "caravans" as a political prop. Watching him preside over a naturalization ceremony last night was like watching a fox bless a henhouse (Х. Клінтон, 26.08.2020). У наведеному прикладі 3 метою дискредитації політичного опонента вжито лексему негативнооцінної семантики «demonizing», що вступає в контекстуальну семантичну опозицію до позитивно оцінної лексеми «babies». Таке протиставлення сприймається адресатами як концептуальна опозиція релігійного характеру демони / янголи, де Д. Трамп ототожнюється 3 демоном, а немовляти - мігрантів з янголами. Крім того, вживання фразеологізму «а fox bless a henhouse» містить імпліцитну оцінку опонента та його характеристику як підступної людини. Тут спостерігаємо використання оцінної лексики, семантичних опозицій і фразеологізмів із метою звинувачень політичного опонента.

При цьому дискредитація може мати й імпліцитний характер, коли політичний опонент не названий: відсутня як пряма адресація, так i апеляція до конкретної особи 3 використанням імені або прізвища. У такому разі негативно оцінні лексеми вжито на позначення політичних опонентів загалом або характеристики чинної ситуації в країні, напр.: Eight weeks from today we have the opportunity to choose democracy over creeping authoritarianism. Dignity and respect over corruption and lawlessness. Building back better over continued chaos. A plan over a pandemic. Unity over division (Х. Клінтон, 17.09.2020). Наявне протиставлення демократія / авторитаризм визначає й оцінку мовця та його політичних опонентів загалом. Зважаючи на це, дискредитація політичних опонентів реалізується і в неперсофінікованій формі, напр.: Щиро дивуюся монобільшості. Як можна було сьогодні голосувати рішення про відставку голови НБУ, не призначаючи в цуей же день нового голову? Фактично сьогодні інституція обезголовлена. І світова преса знову пише про скандал в Україні (А. Яценюк, 3.07.2020). Жанрові вимоги твіту потребують пошуків лаконічних й одночасно влучних форм влучних вираження вербального конфлікту, тому політична термінологія (монобільшість) тут використовується 3 експресивно-оцінним забарвленням, що посилюється вживанням лексеми «скандал» як характеристики наслідків описаних дій.

Розглянемо основні тактики конфліктної комунікативної взаємодії в політичному твітингу.

КТ звинувачення полягає у «приписуванні кому-небудь провини, визнання себе винним, а також викриття певних негативних дій, намірів, якостей» (Михалева, 2009: 47). Здебільшого адресант коментує певну ситуацію, роль у якій свого політичного опонента оцінює негативно, звинувачуючи його у проблемі чи кризі, напр.: Today, White House Chief of Staff Mark Meadows said, "We are not going to get control of the pandemic».

The Trump administration would rather let tens of thousands of Americans unnecessarily die than listen to scientists and create a national plan. They must be defeated (Б. Сандерс, 25.10.2020). У такому разі фіксуємо номінацію політичного опонента - або у формі вживання антропонімів (ім'я, прізвище), або перефразів, або описово. Зазначимо, що для американських політиків характерна імпліцитна вказівка на політичного опонента (так, Д. Сандерс або Дж. Байден відкрито звинувачують Д. Трампа, 
а Д. Трамп - відповідно - своїх опонентів), напр.: It's clear Donald Trump will stop at nothing to tear down Obamacare. We can't let him (Дж. Байден, 25.10.2020); Joe Biden was very disrespectful to President Obama at last night's debate when he said that he, Joe, "was Vice President, not President," when trying to make excuses for their failed immigration policies. I wonder what " $O$ " was thinking when he heard that one? (Д. Трамп, 23.10.2020).

В українському політичному дискурсі переважає імпліцитна вказівка на суб'єкта звинувачення, тобто читачі повинні самі ідентифікувати політичного опонента, напр.: Я розумію, що біля вагону Сердючки йому комфортніше, ніж біля танку. Не так лячно. Ви зрозуміли, про кого я? Він не розуміє значення параду ні для самих військових, ні для суспільства. Бо сильні ми не тільки бронею, але й духом перемоги (П. Порошенко, 24.08.2020). $\mathrm{У}$ наведеному твіті взагалі відсутні антропоніми або апелятиви, що вказують на конкретного політика. Утім, контекст, а також використання займенників і запитання допомагає читачам зрозуміти, про кого йдеться в тексті. В українському мережевому дискурсі політики також апелюють до своїх опонентів, називаючи їх на прізвище або ім'я, але домінує саме імпліцитна форма звинувачення.

КТ образи $є$ вираженням вербальної агресії та агресивної мовленнєвої поведінки. На думку А. Баранова, образа як мовленнєвий акт «обов’ язково скеровано на конкретну особу - адресата образи» (Баранов, 2007: 541). Крім того, образа вимагає використання відповідних мовних виразів, що містять негативну характеристику адресата, напр.: Donald Trump will go down in history not just as a racist, sexist, xenophobe and religious bigot. He will be remembered as a demagogue who, more than anyone else, attempted to undermine the rule of law and destroy American democracy. He will not be missed (Б. Сандерс, 16.11.2020). Наведення негативно оцінних лексем на позначення адресата або конкретного суб'єкта (у цьому прикладі опосередкованого адресата) свідчить про реалізацію тактики образи.

Мовними маркерами вираження образи виступають лексеми оцінної семантики, стилістично знижена лексика, інвективи тощо, що мають пряму адресацію або апеляцію до політика-опонента, напр.: When we needed Donald Trump to tell the truth about COVID-19, he lied to us. When we needed him to take action to contain its spread, he spent his days golfing. When we needed a president the most, he was nowhere to be found. It's unforgivable (Дж. Байден, 18.09.2020). Вказівки у формі твердження на те, що Д. Трамп бреше, тотожне використанню оцінної номінації «брехун».
В українському політичному твітингу образи представлені меншою мірою, як і у випадку з тактикою звинувачення: мовці здебільшого обирають імпліцитну форму дискредитації опонентів. Однак КТ представлено у формі опосередкованих оцінок, напр.: Лукашенко, похоже, совсем свихнулся на своей власти и паранойи вокруг этого. Несёт полную чушь. Тексты, вероятно, получил у Путина. Но, если кто-то сходит с ума - не значит, что все должны действовать также! (А. Аваков, 17.09.2020). У наведеному твіті маємо імплікатуру: «Лукашенко збожеволів від влади = Лукашенко божевільний»; «Лукашенко несе дурню = Лукашенко дурень». Уналежнення таких твітів до тактики образи стає можливим завдяки використанню лексичних одиниць негативно оцінної семантики, що адресовані політику.

КТ критики характеризується високим ступенем аргументативності: загалом негативно оцінюючи дії, вчинки, виступи політичних опонентів, дописувачі вдаються до переконливої мотивації своїх оцінок, напр.: Why would an incumbent president who has been in office for four years try to discourage people from voting? It's because he knows he cannot run on his record. He knows that, if enough people vote, he will lose (K. Xapрис, 22.10.2020). 3 огляду на це тактика критики передбачає логічну побудову твіту: наявність причинно-наслідкового зв'язку, що виражається передусім у використанні складнопідрядних речень із підрядними причини і наслідку, а також діалогічних єдностей. В останньому випадку мовець ставить проблемне питання, на яке сам і відповідає, або адресує запитання читачам, напр.: У березні Зеленський обіияв, що не буде «ніяких люксових палат для членів ЦК $і$ в жодного політика не буде краших умов, ніж у звичайного украӥнця». Ви не знаєте, де зараз всі ці «члени ЦК» лікуються? (О. Ляшко, 12.11.2020). У такий спосіб мовець представляє власну позицію на розсуд читачам i імпліцитно закликає їх приєднатися до критики політичного опонента.

Тактика критики скерована на політичного опонента і є виявом конфліктного спілкування, але передбачає не емоційність у вигляді образ i звинувачень, а раціональне пояснення висловлених критичних зауважень, напр.: Вважаю, що депутати ОПЗЖ виконують волю Путіна. Вважаю, що вони використовують свій статус народного депутата України, щцоб просувати інтереси Путіна на території нашої держави. Тому я піду на допит до ДБР $і$ офіиійно звернуся із заявою про скоєння злочину Медведчуком $i$ його сворою (А. Яценюк, 20.11.2020). Завдяки 
цьому суб'єктивна позиція мовця потребує підтвердження та мотивації, що і зумовлює вживання відповідних синтаксичних конструкцій. Актуалізація авторських міркувань із наведенням аргументів у формі питально-відповідних комплексів або складнопідрядних речень причинново-наслідкового типу пов'язано 3 посиленням діалогічного мережевого спілкування: мовець демонструє суперечливі питання, на які знаходить відповіді та пояснення, напр.: At a time of pandemic, economic meltdown and climate change, it is easy to forget that Trump is now working to defund and destroy Social Security a longtime Republican dream. No. We will defeat you and expand Social Security, the most successful anti-poverty program in history (Б. Сандерс, 2.09.2020). У такий спосіб мовець погоджується або не погоджується із власними твердженнями, що уможливлює вербалізацію процесу критичного переосмислення проблеми та експлікацію аргументації. В американському та українському політичному твітингу КТ критики представлена однаковою мірою.

КТ самокритики передбачає неконструктивну критику, скеровану мовцем на власну адресу: в такий спосіб критикують власні дії, власну політичну силу, власну країну і народ. Здебільшого ця стратегія характерна для українського політичного дискурсу, напр.: Чому Чехія, Польща, Угорщина, країни Балтії стрімко рвонули у розвитку, а Україна - ні? Чому в них є економічна стабільність, а у нас - ні? Бо свого часу усі вони провели повноиінну люстрачію влади. А Україна - ні. Ми так $і$ не завершили жодної з трьох революиій (О. Тягнибок 21. 08.2020). У цьому разі мовець вдається до самокритики, зокрема ототож- нюючи себе 3 країною: наголошує на помилках, проблемах і кризі. На нашу думку, КТ самокритики, що $є$ автоадресованою, характерна саме для українських політиків, які вдається до негативних оцінок власної діяльності та держави загалом, напр.: Парадокс иих місиевих виборів у тому, що в результаті них немае жодної загальноначіональної партії, яка виграла вибори. Тобто місчеві вибори показали, щчо народ Украйни не довіряє жсодній загальнонаціональній партії. I це дуже тривожний сигнал (А. Яценюк, 25.10.2020). Оприлюднення в соцмережі негативних оцінок щодо власної діяльності та ситуації у країні значною мірою впливає на загальне ставлення читачів до порушених проблем. У такий спосіб політики не лише демонструють критичне ставлення до власної діяльності, а й дають узагальнені коментарі принизливого характеру, що не сприяє виробленню конструктивного ставлення пересічних громадян до політичної ситуації в країні. Натомість у політичному твітингу США такого явища не спостерігаємо.

Висновки i перспективи дослідження. У політичному мережевому дискурсі в межах конфліктної комунікації політиків-мовців виокремлено тактики звинувачення, образи, критики і самокритики. Тактики звинувачення та критики, образи представлені в комунікативній поведінці американських та українських політиків однаковою мірою, проте в політиків США їх реалізація має експліцитний характер, а в українських політиків здебільшого імпліцитний характер. Тактика самокритики характерна виключно для українського політичного твітингу. Перспективи дослідження полягають у розробленні типології стратегій і тактик мережевого політичного дискурсу.

\section{СПИСОК ВИКОРИСТАНИХ ДЖЕРЕЛ}

1. Баранов А. Н. Лингвистическая экспертиза текста. Теоретические основания и практика. Москва : Флинта, Наука, 2007. 592 с.

2. Грайс Г. П. Логика и речевое общение. Новое в зарубежной лингвистике: Лингвистическая прагматика. Вып. XVI. Москва : Прогресс, 1985. С. 217-237.

3. Иссерс О. С. Коммуникативные стратегии и тактики русской речи. Москва : УРСС, 2003. 286 с.

4. Михалева О. Л. Политический дискурс: Специфика манипулятивного воздействия. Москва : Книжный дом «ЛИБРОКОМ», 2009. $256 \mathrm{c}$.

5. Седов К. Ф. Дискурс и личность: Эволюция коммуникативной компетенции. Москва : Лабиринт, 2004. 320 с.

6. Селіванова О. О. Сучасна лінгвістика: напрями та проблеми. Полтава : Довкілля-К, 2008. 712 с.

7. Славова Л. Л. Мовна особистість лідера у дзеркалі політичної лінгвоперсоналогії: США - Україна. Житомир : Вид-во ЖДУУ ім. І. Франка, 2012. 360 с.

\section{REFERENCES}

1. Baranov A. N. Lingvisticheskaya ekspertiza teksta. Teoreticheskiye osnovaniya i praktika [Linguistic examination of the text. Theoretical foundations and practice). Moscow: Flinta, Nauka, 2007. 592 p. [in Russian).

2. Grais H. P. Logika i rechevoye obshcheniye [Logic and speech communication). New in Foreign Linguistics: Linguistic Pragmatics. Issue XVI. Moscow: Progress, 1985. pp. 217-237. [in Russian).

3. Issers O. S. Kommunikativnyye strategii i taktiki russkoy rechi [Communicative strategies and tactics of Russian speech). Moscow: URSS, 2003. 286 p. [in Russian). 
4. Mykhaleva O. L. Politicheskiy diskurs: Spetsifika manipulyativnogo vozdeystviya [Political discourse: The specifics of manipulative influence.). Moscow: Knizhnyj dom «LIBROKOM», 2009. 256 p. [in Russian).

5. Sedov K. F. Diskurs i lichnost': Evolyutsiya kommunikativnoy kompetentsii [Discourse and personality: The evolution of communicative competence). Moscow: Labirint, 2004. 320 p. [in Russian).

6. Selivanova O. O. Suchasna linhvistyka: napryamy ta problemy [Modern linguistics: directions and problems). Poltava: Dovkillia-K, 2008. 712 p. [in Ukrainian).

7. Slavova L. L. Movna osobystist' lidera u dzerkali politychnoyi linhvopersonalohiyi: SSHA - Ukrayina [Language personality of the leader in the mirror of political linguistics: USA - Ukraine). Zhytomyr: Vyd-vo ZhDUU im. I. Franka, 2012. 360 p. [in Ukrainian). 